\title{
HUBUNGAN ANTARA DEPRESI, KECEMASAN DAN STRESS DENGAN MOTIVASI BERPRESTASI ATLET PUTRI SELAMA PANDEMI COVID 19
}

\section{THE CORRELATION BETWEEN DEPRESSION, ANXIETY AND STRESS AND WOMEN ATHLETE ACHIEVEMENT MOTIVATION DURING COVID 19}

\author{
Dita Yuliastrid ${ }^{*}$, Suryanto², dan Anung Priambodo ${ }^{3}$ \\ 1Program Studi Ilmu Keolahragaan, Universitas Negeri Surabaya, Surabaya, Indonesia \\ ${ }^{2}$ Fakultas Psikologi, Universitas Airlangga, Surabaya, Indonesia \\ ${ }^{3}$ Program Studi Pendidikan Jasmani Kesehatan dan Rekreasi, Universitas Negeri Surabaya, Surabaya, \\ Indonesia
}

*Corresponding Author: Dita Yuliastrid, ditayuliastrid@unesa.ac.id

Received: 2021-06-07; Revised: 2021-10-20; Accepted: 2021-10-21

\begin{abstract}
Abstrak
Tujuan penelitian ini adalah untuk mendeskripsikan hubungan depresi, kecemasan dan stress terhadap motivasi berprestasi pada atlet putri selama pandemi. Penelitian ini menggunakan metode penelitian pendekatan kuantitatif. Sampel yang digunakan adalah atlet putri yang berjumlah 65 orang. Teknik pengumpulan data menggunakan kuesioner Depresion Anxiety Stress Scale 42 (DASS 42) dan kuisioner motivasi berprestasi melalui google form. Analisis data dilakukan menggunakan teknik korelasi tau Kendal dengan bantuan program SPSS 21. Hasil penelitian pada taraf signifikansi 0,000 $(\mathrm{p}<0,05)$ menunjukkan adanya korelasi negatif antara depresi dan motivasi, kecemasan dan motivasi, serta stress dan motivasi. Kesimpulannya, semakin tinggi tingkat depresi, kecemasan dan stress maka semakin rendah motivasi berprestasi atlet, hubungan antara depresi dengan motivasi berprestasi pada kategori kuat, kecemasan dengan motivasi berprestasi pada kategori sedang, dan antara stress dengan motivasi berprestasi pada kategori sedang.
\end{abstract}

Kata Kunci: depresi, kecemasan, stress, motivasi berprestasi, atlet, covid 19

\begin{abstract}
The purpose of this study was to describe the relationship, anxiety and stress on achievement motivation in female athletes during the pandemic. This research uses a quantitative approach method. The sample used was female athletes who opened 65 people. The data collection technique used a Depression Anxiety Stress Scale 42 (DASS 42) questionnaire and a achievement motivation questionnaire via google form. Data analysis was performed using the Kendal tau correlation technique with the SPSS 21 assistance program. The results at a significance level of $0.000(p<0.05)$ showed a negative correlation between depression and motivation, anxiety and motivation, and stress and motivation. In conclusion, the higher the level of depression, anxiety and stress, the lower the athlete's achievement motivation, the relationship between depression and achievement in the strong category, anxiety and achievement in the moderate category, and between stress and achievement in the moderate category.
\end{abstract}

Keywords: depression, anxiety, stress, achievement motivation, athlete, covid 19

How To Cite: Yuliastrid, D., Suryanto, S., Priambodo, A. (2021). Hubungan antara depresi, kecemasan dan stress dengan motivasi berprestasi atlet putri selama pandemi covid 19. Journal of Sport Education (JOPE), 4 (1), $30-$ 39. doi:http://dx.doi.org/10.31258/jope.4.1.30-39

Journal Of Sport Education (JOPE) is an open access article under the CC-BY-SA 4.0

\section{PENDAHULUAN}

Pandemi Covid 19 telah mengakibatkan dampak secara global bagi kehidupan Copyright (c) The Author (s) 2021

ISSN 2654-4474 (Print), ISSN 2654-9069 (Online) 
masyarakat, tak terkecuali bagi atlet, yang secara signifikan mengganggu psikologis. Wabah virus Covid 19 telah menghancurkan jadwal olahraga dan mempengaruhi beberapa event terbesar di tahun 2020. Atlet yang semula sibuk dengan jadwal latihan yang hampir tiap hari dan aktif mengikuti berbagai event pertandingan, mendadak harus melakukan isolasi di rumah dan menghentikan segala aktivitas di luar rumah. Belum lagi beberapa pertandingan yang harus ditunda bahkan dibatalkan. Peristiwa tersebut terjadi di seluruh dunia termasuk di Indonesia. Misalnya dengan tertundanya penyelenggaraan PON di Papua tahun 2020 serta diberhentikan kompetisi-kompetisi yang ada di Indonesia, hal ini adalah sebagai salah satu upaya untuk menghindari terjadinya kerumunan banyak orang sehingga dapat mencegah penyebaran virus Covid 19 (Kemenpora, 2020). Tidak jarang dengan adanya pandemi ini atlet mengalami depresi, kecemasan dan stress, hal tersebut sejalan dengan pendapat dari (Szczypińska et al., 2021) yang mengatakan bahwa situasi pandemi adalah stresor eksternal yang kuat yang mempengaruhi seluruh masyarakat, yang dapat menyebabkan stres bagi semua orang yang mengalaminya dan dapat menyebabkan perasaan tidak berdaya dan hilangnya rasa aman yang mendasar, termasuk perlindungan, stabilitas dan kemampuan untuk memprediksi masa depan sendiri (Shigemura et al., 2020). Pernyataan tersebut juga diperkuat oleh (di Fronso et al., 2020) bahwa selama COVID-19, iklim ketidakpastian terjadi dalam dunia olahraga, misalnya terjadi pembatalan acara dan revisi kontrak atlet dengan klub olahraga, dan hal tersebut kemungkinan besar berkontribusi memperburuk keadaan psikologis atlet. Dan menurut (Mehrsafar et al., 2020) atlet sama rentannya dengan populasi umum terhadap konsekuensi psikologis negatif COVID-19, seperti stres, kecemasan, dan depresi.

Menurut Dr. William C. Shiel, sebagaimana diterapkan pada konteks medis atau biologis, stres adalah faktor fisik, mental, atau emosional yang menyebabkan ketegangan tubuh atau mental. Stres dapat bersifat eksternal (dari lingkungan, psikologis, atau situasi sosial) atau internal (penyakit, atau dari prosedur medis). Stres juga dapat memicu respons yang merupakan reaksi dari sistem endokrinologi dan neurologis. Stres sangat sering menyebabkan dan berkontribusi besar pada kondisi psikologis kecemasan dan depresi (Brosh, 2020).

Stres merupakan hal yang tidak bisa dihindari dalam kehidupan. Yang penting adalah bagaimana dapat terhindar dari distres walaupun harus hidup dengan stres. Orang yang depresi biasanya memiliki komponen cemas, dan sebaliknya. Manifestasi depresi tidak selalu muncul dalam bentuk penyakit mental, tetapi juga dapat muncul dalam bentuk ketidaknyamanan fisik, atau yang biasa disebut dengan depresi terselubung, yaitu ketidaknyamanan fisik dengan latar belakang depresi (Jamil, 2019). Berdasarkan teori psikoanalisis Sigmund Freud seseorang memiliki mental sehat apabila tidak mengalami keluhan tertentu misal kecemasan, rendah diri, tegang dan lain-lain, yang dapat menyebabkan perasaan sakit. Pikiran-pikiran yang direpres atau ditekan merupakan sumber perilaku yang tidak normal atau menyimpang. Pandangan Freud mengenai psikoanalisis meliputi kesadaran dan ketidaksadaran serta insting dan kecemasan (di dalamnya terdapat defense mechanism).

Beberapa penelitian telah melaporkan bahwa implikasi kesehatan mental dari COVID-19 telah mengidentifikasi peningkatan prevalensi depresi dan cemas dari sedang sampai berat di kalangan masyarakat umum (Cuiyan et al., 2020) yang mencerminkan efek ketidakpastian yang meluas dan ketakutan yang berhubungan dengan kesehatan. Pada atlet, mengalami gangguan psikologis tersebut bisa disebabkan karena kejenuhan melakukan latihan akibat penundaan event, (Kemenpora, 2020). Kurangnya sosialisasi akibat social distancing serta kekhawatiran akan tertular virus Covid 19 (Mahfud \& Gumantan, 2020). Situasi isolasi saat ini dapat menjadi sumber stres yang dapat dirasakan dan menyebabkan meningkatnya tingkat kecemasan, yang dihasilkan dari persepsi kurangnya kontrol untuk beradaptasi dengan tuntutan kontekstual, pengenaan pembatasan kebebasan (Halabchi et al., 2020). 
Secara umum, kecemasan adalah keadaan emosional negatif yang ditandai dengan kegugupan, kekhawatiran, dan ketakutan dan terkait dengan aktivasi atau gairah tubuh. Kecemasan bisa juga mengacu pada keadaan psikologis yang tidak menyenangkan sebagai reaksi terhadap stres yang dirasakan mengenai kinerja tugas di bawah tekanan. Kecemasan memiliki komponen pikiran (misalnya, khawatir dan ketakutan) yang disebut kecemasan kognitif. Ketika tubuh dan pikiran bereaksi terhadap bahaya atau ancaman, seseorang merasakan sensasi fisik kecemasan dan bisa muncul saat sedang stres, dan ditandai oleh perasaan khawatir dan ketakutan (Weinberg \& Daniel, 2019). Berdasarkan penelitian yang sudah dilakukan stress dan gangguan mood dialami lebih tinggi terjadi pada atlet wanita dibanding atlet pria, hal ini disebabkan karena wanita cenderung untuk merenung ketika mengalami suasana hati yang negatif, sedangkan pria cenderung mengalihkan perhatiannya. Perenungan ini yang dapat menyebabkan meningkatnya gangguan mood pada wanita (di Fronso et al., 2020).

Setiap manusia memiliki motivasi yang berbeda karena tingkat kebahagiaan seseorang berbeda satu orang dengan yang lain. Ada yang berasal dari diri sendiri, ada yang dari orang lain, keinginan untuk meraih sesuatu dan ada juga yang datang dari faktor kesehatan (Ridwan M, Sudibyo, 2020). Motivasi merupakan sebuah dorongan, keinginan atau pun minat yang begitu besar di dalam diri kita, untuk mencapai suatu tujuan tertentu. Adanya motivasi akan membuat individu berusaha sekuat tenaga untuk mencapai tujuan yang diinginkannya. Seseorang yang memiliki motivasi tinggi akan memberikan dampak yang positif bagi kehidupannya. Tingginya motivasi tersebut akan mengubah sikap dan perilakunya, dalam menggapai cita-cita dan menjalani hidup dengan lebih baik (Sari, 2020). Motivasi dapat diartikan sebagai kekuatan seseorang yang dapat menimbulkan tingkat persistensi dan antusiasmenya dalam melaksanakan suatu kegiatan, baik yang bersumber dari dalam diri individu (instrinsik) maupun dari luar individu (ekstrinsik). Teori motivasi Mc. Clelland memfokuskan pada tiga motivasi yaitu: "a) motivasi prestasi, b) motivasi afiliasi dan c) motivasi kekuasaan." Motivasi berprestasi dapat diartikan sebagai kecenderungan untuk berperilaku baik berdasarkan standar yang terbaik, seseorang yang mempunyai kebutuhan untuk berprestasi yang kuat cenderung memiliki keinginan untuk sukses dalam menuntaskan pekerjaan yang menantang, tidak untuk mendapatkan keuntungan status, tetapi hanya untuk berbuat baik (Husdarta, 2018). Motivasi berprestasi merupakan suatu hal yang sangat penting dalam proses latihan. Setidaknya pelatih harus memiliki motivasi berprestasi untuk meningkatkan kegairahan dalam pelaksanaan proses latihan tanpa motivasi berprestasi sukar bagi pelatih untuk mengembangkan diri seorang atlet selama proses latihan. Tidak ada pencapaian tanpa motivasi. seperti yang dikatakan Cratty, penelitian tentang kecemasan dan motivasi dalam prestasi atletik menunjukkan bahwa tingkat kecemasan rendah dan motivasi tinggi mengarah pada peningkatan kinerja atletik (Effendi, 2016).

Hasil penelitian yang dilakukan oleh (Ruffault et al., 2020) menunjukkan bahwa antara kelompok atlet kompetitif dengan tingkat dan kebiasaan pelatihan yang berbeda selama masa lockdown COVID-19 di Prancis, terdapat skor kecemasan yang lebih tinggi untuk wanita, atlet yang lebih muda, atlet yang berlatih dan berkompetisi di level tertinggi, dan atlet tanpa program pelatihan selama lockdown. Sedangkan untuk skor motivasi lebih rendah untuk atlet yang lebih tua, atlet yang berlatih selama lebih dari 10 tahun, dan atlet tanpa program pelatihan selama lockdown. Motivasi atlet internasional lebih terkontrol daripada atlet nasional dan regional. Namun hasil tersebut bertentangan dengan penelitian yang dilakukan oleh (Clemente-Suárez et al., 2020) yang menunjukkan bahwa kecemasan lebih rendah dan stres yang dirasakan di antara atlet elit selama krisis COVID-19 dibandingkan dengan populasi umum atau atlet kompetitif non-elit. Di Indonesia, hingga saat ini masih terbatas adanya literatur hasil penelitian tentang gambaran psikologis atlet putri yang meliputi depresi, kecemasan dan stress serta hubungannya dengan motivasi berprestasi selama 
Pandemi Covid 19. Oleh karena itu penelitian ini penting dilakukan untuk memperoleh gambaran hubungan depresi, kecemasan dan stress terhadap motivasi berprestasi pada atlet putri selama pandemi.

\section{METODE}

Penelitian ini menggunakan metode penelitian pendekatan kuantitatif. Sampel yang digunakan dalam penelitian ini adalah atlet putri yang berjumlah 65 orang. Pengambilan sampel melalui purposive sampling. Pengumpulan data dilakukan dengan metode kuesioner yang terdiri dari dua bagian, yaitu kuesioner untuk mengukur depresi, kecemasan dan stress menggunakan Depresion Anxiety Stress Scale 42 (DASS 42) dan kueisioner motivasi. Proses pengumpulan data ini dilakukan dengan membagikan kuesioner melalui link google form. Kuesioner DASS 42 dari Lovibond, S.H \& Lovibond, P.F tahun 1995 (Muttaqin \& Ripa, 2021). DASS 42 adalah kueisioner yang terdiri dari 42 pertanyaan dengan masing-masing 14 pertanyaan untuk mengukur adanya depresi, kecemasan dan stress. Kuesioner motivasi yang diberikan kepada responden sudah diuji validitas dan reliabilitasnya.

Berdasarkan hasil pengujian validitas item dengan menggunakan rumus product moment, dapat diketahui hasil dari 25 item yang diajukan terhadap 65 responden diperoleh hasil semua item valid dengan nilai $r>r$ tabel $(0,244)$; yaitu pada rentang 0,272 - 0,804, sehingga bisa dikatakan bahwa kuesioner tersebut valid. Hasil uji coba reliabilitas dengan menggunakan rumus alpha didapatkan Cronbach's alpha $=0,932$; karena nilainya lebih besar dari $r$ tabel maka dapat disimpulkan bahwa kuesioner tersebut reliabel. Analisis data pada penelitian ini menggunakan analisis deskriptif presentase, dan uji korelasi antara depresi, kecemasan dan stress terhadap motivasi berprestasi atlet putri menggunakan teknik korelasi tau Kendal dengan bantuan program SPSS 21.

\section{HASIL}

Berikut ini adalah hasil pengukuran tingkat depresi, kecemasan dan stress pada atlet putri. Data tersebut diperoleh melalui kueisioner yang dibagikan kepada responden dengan link google form. Data yang ada kemudian dianalisis seperti yang terlihat pada tabel 1.

Tabel 1. Tingkat Depresi, Kecemasan dan stress atlet putri $(n=65)$

\begin{tabular}{cccc}
\hline Status Mental & Kategori & Frekuensi & Presentase (\%) \\
\hline Depresi & Normal & 35 & 53,85 \\
& Ringan & 12 & 18,46 \\
& Sedang & 14 & 21,54 \\
& Parah & 2 & 3,08 \\
& Sangat Parah & 2 & 3,08 \\
Kecemasan & Normal & 15 & 23,08 \\
& Ringan & 9 & 13,85 \\
& Sedang & 18 & 27,69 \\
& Parah & 12 & 18,46 \\
& Sangat Parah & 11 & 16,92 \\
& Normal & 35 & 53,85 \\
& Ringan & 10 & 15,38 \\
& Sedang & 17 & 26,15 \\
& Parah & 3 & 4,62 \\
& Sangat Parah & 0 & 0 \\
\hline
\end{tabular}

Berdasarkan tabel 1 tingkat depresi atlet putri, sebanyak 53,85\% dalam keadaan normal, $18,46 \%$ ringan, $21,54 \%$ sedang, 3,08\% parah dan 3,08\% sangat parah. Tingkat 
kecemasan atlet putri, sebanyak 23,08\% dalam keadaan normal, 13,85\% ringan, 27,69\% sedang, 18,46\% parah dan 16,92\% sangat parah. Tingkat stress atlet putri, sebanyak 53,85\% dalam keadaan normal, 15,38\% ringan, 26,15\% sedang, 4,62\% parah dan $0 \%$ sangat parah.

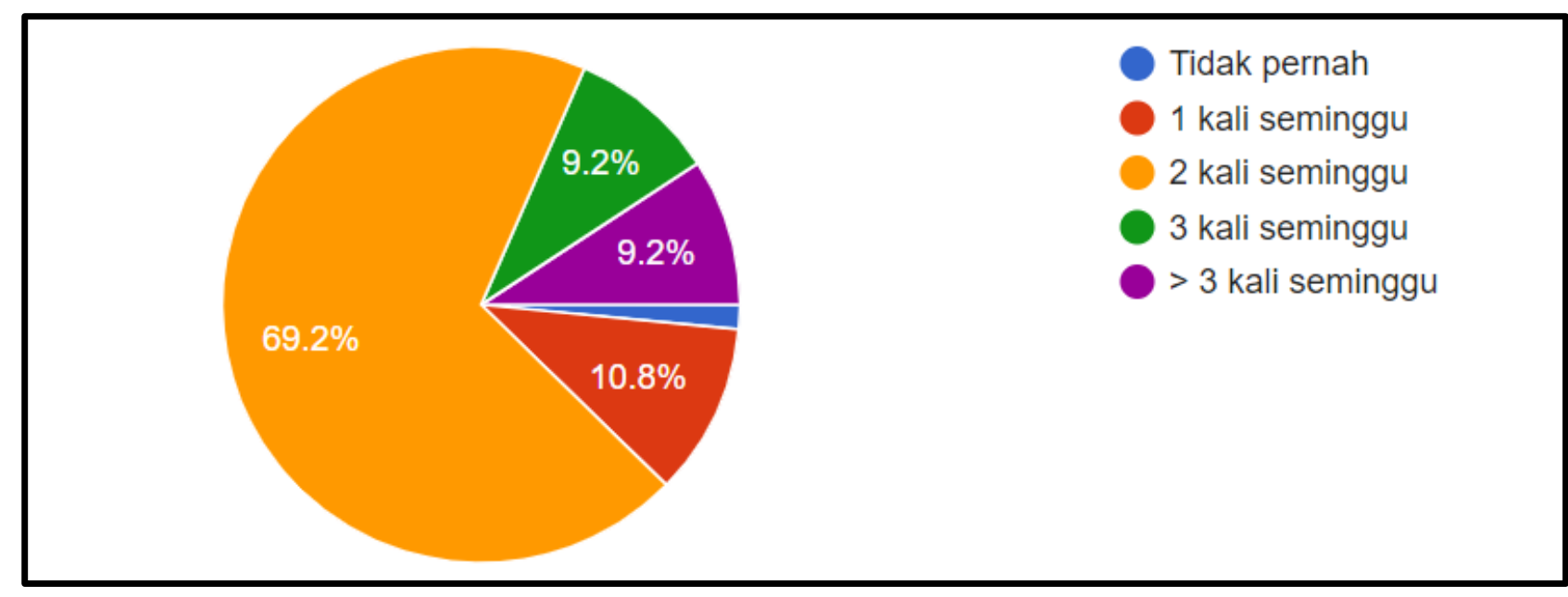

Gambar 1. Diagram frekuensi latihan atlet putri dalam seminggu

Pada gambar 1 menunjukkan frekuensi latihan atlet putri selama masa Pandemi Covid 19 dalam seminggu, 69,2\% atlet melakukan latihan 2 kali seminggu.

Tabel 2. Tingkat Motivasi berprestasi atlet putri $(n=65)$

\begin{tabular}{lcc}
\hline \multicolumn{1}{c}{ Tingkat Motivasi } & Frekuensi & Presentase (\%) \\
\hline Sangat Tinggi & 29 & 44,62 \\
Tinggi & 17 & 26,15 \\
Sedang & 16 & 24,62 \\
Rendah & 2 & 3,08 \\
Sangat Rendah & 1 & 1,54 \\
\hline
\end{tabular}

Tabel 3. Hasil korelasi depresi, kecemasan dan stress terhadap motivasi berprestasi atlet

\begin{tabular}{lcc}
\multicolumn{3}{c}{ putri $(\mathrm{n}=65)$} \\
\hline Variabel & $\mathbf{R}$ & sig \\
\hline Depresi & $-0,65$ & $0,000^{* *}$ \\
Kecemasan & $-0,57$ & $0,000^{* *}$ \\
Stress & $-0,51$ & $0,000^{* *}$ \\
\hline
\end{tabular}

** Correlation is significant at the 0,01 level (2-tailed)

Berdasarkan tabel 2 tingkat motivasi atlet putri, sebanyak 44,62\% sangat tinggi, 26,15\% tinggi, 24,62\% sedang, 3,08\% rendah dan 1,54\% sangat rendah. Uji korelasi depresi, kecemasan dan stress terhadap motivasi berprestasi atlet putri menggunakan teknik korelasi tau Kendal dengan bantuan program SPSS 21. Berdasarkan tabel 3, hasil analisis korelasi antara depresi dan motivasi adalah $-0,65$ dengan nilai signifikansi sebesar $0,000(\mathrm{p}<0,05)$, korelasi antara kecemasan dan motivasi adalah -0,57; dengan nilai signifikansi sebesar 0,000 $(\mathrm{p}<0,05)$, korelasi antara stress dan motivasi sebesar $-0,51$ dengan nilai signifikansi sebesar $0,000(\mathrm{p}<0,05)$. Tanda negatif pada nilai koefisien korelasi tersebut berarti bahwa terdapat hubungan negatif yang signifikan antara variabel depresi, kecemasan dan stress terhadap motivasi berprestasi atlet, yang memiliki arti bahwa semakin tinggi tingkat depresi, kecemasan dan stress maka semakin rendah motivasi berprestasi atlet, Adapun kuatnya hubungan antara depresi dengan motivasi berprestasi berada pada kategori kuat, kecemasan 
dengan motivasi berprestasi berada pada kategori sedang, dan antara stress dengan motivasi berprestasi berada pada kategori sedang.

\section{PEMBAHASAN}

Pandemi covid 19 membawa dampak yang luar biasa di seluruh dunia dan di berbagai bidang. Penyebaran virus Covid-19 telah menyebabkan penutupan bisnis, tempat kerja, ibadah dan keterlibatan sosial, sekolah dan universitas yang belum pernah terjadi sebelumnya. Penularan virus yang cepat, yang sejauh ini telah menyebabkan hilangnya lebih dari satu juta nyawa manusia di seluruh dunia, mengakibatkan olahraga dan acara olahraga telah dibatalkan, ditunda atau diubah sehingga kompetisi dapat berlangsung tetapi tanpa penonton. Tim dan organisasi olahraga elit telah mengalami dampak finansial langsung dengan kerugian karena kurangnya penonton langsung, bukan hanya olahraga elit yang terkena dampaknya, klub dan organisasi olahraga rekreasi, termasuk gym, kolam renang, lapangan golf, dan sebagainya, juga terpukul secara finansial (Grix et al., 2021).

Hal yang sama juga terjadi di Indonesia, yaitu dengan ditundanya berbagai event pertandingan seperti PON Papua yang seharusnya diadakan di tahun 2020 mundur menjadi tahun 2021, belum lagi gagalnya kompetisi seperti liga 1 . Kejadian ini menyebabkan kerugian dari berbagai pihak baik atlet, pelatih, penyelenggara maupun penonton. Tujuan dari penundaan tersebut adalah untuk mencegah penyebaran virus Covid 19. Atlet yang semula rutin latihan di luar rumah, diharuskan untuk melakukan aktivitas latihan sendiri di dalam rumah. Ada kemungkinan dengan banyak aktivitas yang dilakukan di rumah membuat atlet merasa jenuh dan bosan. Kejenuhan dan kebosanan yang berkepanjangan akan membawa dampak psikologis yang lebih serius bagi atlet. Pada awal tahun 2021, pemerintah Indonesia mulai melakukan program vaksinasi terhadap beberapa lapisan masyarakat. Vaksin Covid 19 diberikan secara bertahap, mulai dari tenaga kesehatan, TNI/Polri, petugas pelayanan publik, lansia, tenaga pendidik dan atlet. Dengan adanya vaksin dan penerapan protokol kesehatan yang telah dilakukan selama ini, atlet banyak yang aktif melakukan latihan, termasuk atlet putri dalam penelitian ini.

Fakta dalam penelitian ini ditemukan bahwa, sebesar 98,5\% atlet masih berlatih, (gambar 1) dan berdasarkan keterangan yang didapat dari penelitian ini bahwa mereka melakukan latihan secara mandiri selama pandemi seperti jogging, main bola dsb. Selain itu mereka juga melakukan kegiatan yang menyenangkan seperti berkebun, nonton film, dan bermain game dengan handphone. Hal inilah yang menjadi penyebab 53,85\% atlet putri tidak mengalami depresi dan stress. Hal ini sejalan dengan temuan (Lades et al., 2020) yang menunjukkan bahwa seseorang yang melakukan aktivitas sehari-hari dengan berkebun, olahraga dan melakukan hobi yang menyenangkan dapat mengurangi efek buruk selama melakukan pembatasan sosial. Atlet mungkin lebih banyak melakukan aktivitas olahraga dan mampu mengatasi situasi stres dengan lebih baik. Kemungkinan besar, para atlet ini mendapatkan lebih banyak manfaat dari sesi pelatihan yang mensimulasikan kompetisi nyata dan secara efektif belajar bagaimana menangani kemungkinan gangguan dan pemicu stress. Akibatnya, mereka mungkin dapat mentransfer keterampilan ini dari olahraga ke domain kehidupan lain bahkan selama masa-masa sulit (di Fronso et al., 2020). Selain itu kenyataan lain menunjukkan bahwa para profesional olahraga dan kesehatan cenderung berusaha untuk memastikan bahwa para atlet dapat mengatasi situasi yang mengkhawatirkan dengan lebih baik. Di bagian sosiografik dari survei, sebagian besar atlet (80\%) melaporkan melakukan kontak melalui web dengan pelatih atau profesional lainnya. Sangat menyadari bahwa ilmu perilaku apa pun dapat memberikan wawasan berharga untuk mengelola pandemi dan dampaknya (Bavel et al., 2020). Aktivitas fisik dan olahraga yang dilakukan secara rutin memang berkaitan dengan kesehatan mental yang lebih baik yaitu dapat mengurangi terjadinya depresi (Schuch et al., 2018). 
Dalam temuan penelitian ini, sepertinya atlet putri masih merasakan kecemasan terhadap pandemi Covid 19 ini, terlihat berdasarkan data hanya 23,08\% yang tidak merasakan kecemasan sedangkan $76,92 \%$ merasakan kecemasan baik pada tingkat ringan, sedang, parah dan sangat parah. Hasil temuan ini bertentangan dengan penelitian yang dilakukan oleh (Clemente-Suárez et al., 2020) yang menunjukkan kecemasan yang lebih rendah dan stres yang dirasakan di antara atlet elit selama krisis COVID-19 dibandingkan dengan populasi umum atau atlet kompetitif non-elit. Namun penelitian ini menggunakan sample atlet wanita, sehingga sejalan dengan penelitian yang dilakukan oleh (Gao et al., 2020), yang menunjukkan bahwa wanita secara signifikan lebih besar mengalami kecemasan di atas ambang batas normal. Wanita cenderung merenungi suasana hati yang dapat meningkatkan keadaan negatif sehingga dapat berdampak pada pikiran, tubuh dan kecemasan yang tinggi Kecemasan ini berkaitan dengan ketidakpastian berakhirnya pandemi Covid 19.

Perkembangan epidemi akan menyebabkan tekanan psikologis yang lebih besar pada masyarakat. Alasan yang mungkin untuk masalah mental ini terkait dengan "kekhawatiran hipokondria" (khawatir akan terinfeksi) dan khawatir bahwa epidemi sulit dikendalikan Hal tersebut tidak bisa dipungkiri karena pandemi Covid 19 masih belum berakhir, sehingga masih ada kecemasan untuk tertular virus Covid 19 (WHO, 2020). Belum lagi adanya ketidakpastian jadwal kompetisi, kecemasan ekonomi, kekhawatiran efek jangka panjang terhadap gangguan global serta kecemasan tidak lagi bisa bertanding masih dirasakan oleh atlet-atlet tersebut. Adanya ketidakpastian jadwal bertanding dan penundaan beberapa event pertandingan membawa kecemasan tersendiri bagi para atlet, penundaan bagi atlet pemula menyebabkan penundaan pada rencana pengembangan karier, sedangkan pada atlet yang ada di akhir masa karier, penundaan dapat berakibat gagalnya bertanding karena adanya batasan usia. Stresor terkait pandemi seperti risiko/biaya kesehatan, kesulitan ekonomi, kerawanan pangan, dan gangguan pendidikan atau pekerjaan merupakan faktor risiko terjadi kecemasan dan depresi (Porter et al., 2021).

Menurut (Brosh, 2020) hampir setiap orang mengalami sejumlah ketakutan dan perasaan gugup ketika mereka dihadapkan pada situasi yang penuh tekanan. dan perasaan gugup, respon tersebut diharapkan akan kembali ke keadaan fisiologis yang normal setelah dapat melakukan adaptasi, namun beberapa individu akan menunjukkan gejala kecemasan seperti ketakutan yang mungkin berkepanjangan, abnormal, irasional, dan sangat mengganggu fungsi normal sehari-hari. Respon ini, biasa disebut sebagai gangguan kecemasan. Gangguan kecemasan ini seringkali mengganggu hubungan pribadi, prestasi kerja, bahkan fungsi dasar sehari-hari seperti menyetir mobil, bersosialisasi di depan umum, dan aktivitas rutin lainnya. Gangguan kecemasan yang sangat umum adalah gangguan kecemasan umum yang dapat didefinisikan sebagai kecemasan atau kecemasan berlebihan yang terjadi dalam jangka waktu yang lama (setidaknya enam bulan). Gejala kecemasan umum sangat banyak dan meliputi; kesulitan mengendalikan perasaan khawatir, mudah tersinggung, perasaan gelisah atau gelisah, sulit tidur, kelelahan, dan ketegangan otot. (National Institute of Mental Health., 2020).

Fakta lain dari penelitian ini ditemukan bahwa pada 65 orang atlet putri, berdasarkan analisis uji korelasi dengan tau Kendal, diperoleh hubungan negatif antara depresi, kecemaan dan stress terhadap motivasi berprestasi dengan nilai signifikansi sebesar $0,000(p<0,05)$, yang memiliki arti bahwa semakin tinggi tingkat depresi, kecemasan dan stress maka semakin rendah motivasi berprestasi atlet, dan sebaliknya. Dari 65 orang atlet lebih dari 50\% dalam kondisi normal, dan berdasarkan data penelitian menunjukkan bahwa atlet putri memiliki tingkat motivasi berprestasi yang baik. Untuk tingkat motivasi berprestasi atlet putri menunjukkan $44.62 \%$ sangat tinggi dan 26,15\% kategori tinggi, hal ini bisa disebabkan karena atlet putri hampir seluruhnya masih aktif berlatih sendiri di rumah maupun dengan pelatih dan timya. Frekuensi latihan rata-rata $2 \mathrm{X}$ seminggu sebesar $62,9 \%$, bahkan ada yang 
lebih dari $3 \mathrm{X}$ seminggu sebesar 9,2\%. Mereka juga rajin mengikuti program latihan yang sudah ditetapkan dan selalu disiplin dalam mengikuti latihan. Dan saat data ini diambil mereka ada yang sudah kembali mengikuti puslatda, dan berdasarkan data penelitian mereka masih memiliki keinginan yang tinggi untuk mengikuti kejuaraan di tingkat nasional maupun internasional serta untuk menjadi juara dan berprestasi. Adapun kuatnya hubungan antara depresi dengan motivasi berprestasi berada pada kategori kuat, kecemasan dengan motivasi berprestasi berada pada kategori sedang, dan antara stress dengan motivasi berprestasi berada pada kategori sedang. Untuk itu memiliki kepribadian yang adaptif dan tangguh, serta mampu mengendalikan kecemasan merupakan faktor kunci dalam mencapai kesuksesan (Fletcher \& Sarkar, 2012). Atlet yang memiliki program pelatihan (baik dari staf mereka atau dari sumber lain), merasa lebih terkontrol, dan lebih termotivasi secara intrinsik untuk kembali ke olahraga setelah periode isolasi di rumah. Hal ini sejalan dengan model teoritis kembali ke olahraga dalam konteks cedera olahraga. Faktanya, dengan terus berlatih, dan tetap berhubungan dengan pelatih atau atlet lain, menyebabkan atlet memiliki tujuan dalam melakukan aktivitas setiap hari, serta memiliki waktu untuk berlatih. Melakukan aktivitas ekstra dengan berolahraga adalah kondisi ideal untuk menjadi lebih percaya diri dan mengakibatkan sedikitnya penurunan performa sehingga atlet akan senang berlatih olahraga dan berkompetisi lagi (Ruffault et al., 2020).

\section{SIMPULAN}

Gambaran psikologis atlet putri masih dalam kategori normal (tidak depresi dan tidak stress), dan dalam keadaan cemas baik tingkat ringan, sedang, parah dan sangat parah. Kecemasan yang dialami atlet putri dikarenakan pandemi Covid 19 masih belum berakhir dan belum adanya kepastian sampai kapan pandemi ini akan berakhir. Untuk itu memiliki kepribadian yang adaptif dan tangguh, serta mampu mengendalikan kecemasan merupakan faktor kunci dalam mencapai kesuksesan. Namun walaupun demikian motivasi atlet putri untuk berprestasi sangat tinggi. Penting bagi atlet secara rutin melakukan latihan dan selalu aktif berinteraksi dengan pelatih atau teman dalam tim baik secara offline (dengan memperhatikan protokol kesehatan) ataupun online agar siap untuk berkompetisi dan berprestasi di tingkat nasional maupun internasional. Batasan dalam penelitian ini responden yang digunakan hanya pada atlet putri saja. Penelitian lebih lanjut, diharapkan dapat dilakukan penelitian yang serupa dengan responden atlet putra.

\section{DAFTAR PUSTAKA}

Bavel, J. J. V., Baicker, K., Boggio, P. S., Capraro, V., Cichocka, A., Cikara, M., Crockett, M. J., Crum, A. J., Douglas, K. M., Druckman, J. N., Drury, J., Dube, O., Ellemers, N., Finkel, E. J., Fowler, J. H., Gelfand, M., Han, S., Haslam, S. A., Jetten, J., ... Willer, R. (2020). Using social and behavioural science to support covid-19 pandemic response. Nature Human Behaviour, 4(5), 460-471. https://doi.org/10.1038/s41562-020-0884-z

Brosh, R. (2020). The effects of anxiety and depression on collegiate athletes. The State University of New Jersey.

Clemente-Suárez, V. J., Fuentes-García, J. P., de la Vega Marcos, R., \& Martínez Patiño, M. J. (2020). Modulators of the personal and professional threat perception of olympic athletes in the actual covid-19 crisis. Frontiers in psychology, 11(August), 1-7. https://doi.org/10.3389/fpsyg.2020.01985

Cuiyan, W., Riyu, P., Xiaoyang, W., Yilin, T., Linkang, X., Cyrus, S. H., \& C.H., R. (2020). Immediate psychological responses and associated factors during the initial stage of the 
2019 coronavirus disease (covid-19) epidemic among the general population in china. International Journal of Environmental Research and Public Health, 17(5), 1-25.

di Fronso, S., Costa, S., Montesano, C., Di Gruttola, F., Ciofi, E. G., Morgilli, L., Robazza, C., \& Bertollo, M. (2020). The effects of covid-19 pandemic on perceived stress and psychobiosocial states in italian athletes. International Journal of Sport and Exercise Psychology, O(0), 1-13. https://doi.org/10.1080/1612197X.2020.1802612

Effendi, H. (2016). Peranan psikologi olahraga dalam meningkatkan prestasi atlet. Nusantara (Jurnal Ilmu Pengetahuan Sosial), 1(1), 22-30.

Fletcher, D., \& Sarkar, M. (2012). A grounded theory of psychological resilience in olympic champions. Psychology of Sport and Exercise, 13(5), 669-678. https://doi.org/10.1016/j.psychsport.2012.04.007

Gao, W., Ping, S., \& Liu, X. (2020). Gender differences in depression, anxiety, and stress among college students: A longitudinal study from China. Journal of Affective Disorders, 263, 292300. https://doi.org/10.1016/j.jad.2019.11.121

Grix, J., Brannagan, P. M., Grimes, H., \& Neville, R. (2021). The impact of covid-19 on sport. International Journal of Sport Policy and Politics, 13(1), 1-12. https://doi.org/10.1080/19406940.2020.1851285

Halabchi, F., Ahmadinejad, Z., \& Selk-Ghaffari, M. (2020). Covid-19 epidemic: exercise or not to exercise; that is the question! Asian Journal of Sports Medicine, 11(1), 17-19. https://doi.org/10.5812/asjsm.102630

Husdarta. (2018). Psikologi olahraga (cetakan ke). Alfabeta.

Jamil, J. (2019). Sebab dan akibat stres, depresi dan kecemasan serta penanggulangannya. $A l$ Amin: Jurnal Kajian Ilmu Dan Budaya Islam, 1(1), 123-138. https://doi.org/10.36670/alamin.v1i1.6

Kemenpora. (2020). Atasi Kejenuhan Jadi Tantangan Terberat PB Pelti Jalani Pelatnas Ditengah Pandemi Covid-19.

Lades, L. K., Laffan, K., Daly, M., \& Delaney, L. (2020). Daily emotional well-being during the covid-19 pandemic. British Journal of Health Psychology, 25(4), 902-911. https://doi.org/10.1111/bjhp.12450

Mahfud, I., \& Gumantan, A. (2020). Survey of student anxiety levels during the covid-19 pandemic. Jp.Jok (Jurnal Pendidikan Jasmani, Olahraga Dan Kesehatan), 4(1), 86-97. https://doi.org/10.33503/jp.jok.v4i1.1103

Mehrsafar, A. H., Gazerani, P., Moghadam Zadeh, A., \& Jaenes Sánchez, J. C. (2020). Addressing potential impact of covid-19 pandemic on physical and mental health of elite athletes. Brain, Behavior, and Immunity, 87(May), 147-148. https://doi.org/10.1016/j.bbi.2020.05.011

Muttaqin, D., \& Ripa, S. (2021). Psychometric properties of the indonesian version of the 
depression anxiety stress scale: factor structure, reliability, gender, and age measurement invariance. Psikohumaniora: Jurnal Psikologi, 6(1), 61-76. https://doi.org/10.21580/pjpp.v6i1.7815

National Institute of Mental Health. (2020). Anxiety Disorders.

Porter, C., Favara, M., Hittmeyer, A., Scott, D., Sánchez Jiménez, A., Ellanki, R., Woldehanna, T., Duc, L. T., Craske, M. G., \& Stein, A. (2021). Impact of the covid-19 pandemic on anxiety and depression symptoms of young people in the global south: evidence from a fourcountry cohort study. BMJ Open, 11(4), 1-14. https://doi.org/10.1136/bmjopen-2021049653

Ridwan M, Sudibyo, K. D. C. (2020). Aktivitas permainan, cuaca, dan motivasi siswa dalam pembelajaran pendidikan jasmani. JOURNAL OF SPORT EDUCATION (JOPE), 2(2), 7. https://jope.ejournal.unri.ac.id/index.php/jope/index

Ruffault, A., Bernier, M., Fournier, J., \& Hauw, N. (2020). Anxiety and motivation to return to sport during the french covid-19 lockdown. Frontiers in Psychology, 11(December), 1-7. https://doi.org/10.3389/fpsyg.2020.610882

Sari, A. (2020). Motivasi Berlatih Atlet Karate Selama Pandemi Covid-19. Jurnal Ilmu Olahraga Dan Kesehatan, 9(2), 17-31.

Schuch, F. B., Vancampfort, D., Firth, J., Rosenbaum, S., Ward, P. B., Silva, E. S., Hallgren, M., De Leon, A. P., Dunn, A. L., Deslandes, A. C., Fleck, M. P., Carvalho, A. F., \& Stubbs, B. (2018). Physical activity and incident depression: A meta-analysis of prospective cohort studies. American Journal of Psychiatry, 175(7), 631-648. https://doi.org/10.1176/appi.ajp.2018.17111194

Shigemura, J., Ursano, R. J., Morganstein, J. C., Kurosawa, M., \& Benedek, D. M. (2020). Public responses to the novel 2019 coronavirus (2019-ncov) in japan: mental health consequences and target populations. Psychiatry and Clinical Neurosciences, 74(4), 281282. https://doi.org/10.1111/pcn.12988

Szczypińska, M., Samełko, A., \& Guszkowska, M. (2021). Strategies for coping with stress in athletes during the covid-19 pandemic and their predictors. Frontiers in Psychology, 12(March), 1-12. https://doi.org/10.3389/fpsyg.2021.624949

Weinberg, R., \& Daniel, G. (2019). Foundations of Sport and Exercise Psychology 7th Ed.

WHO. (2020). Mental health and psychosocial considerations during covid-19 outbreak. World Health Organization, January, 1-6. file:///C:/Users/muled/Downloads/COVID referances/Mental health and psychosocial considerations during the.pdf 